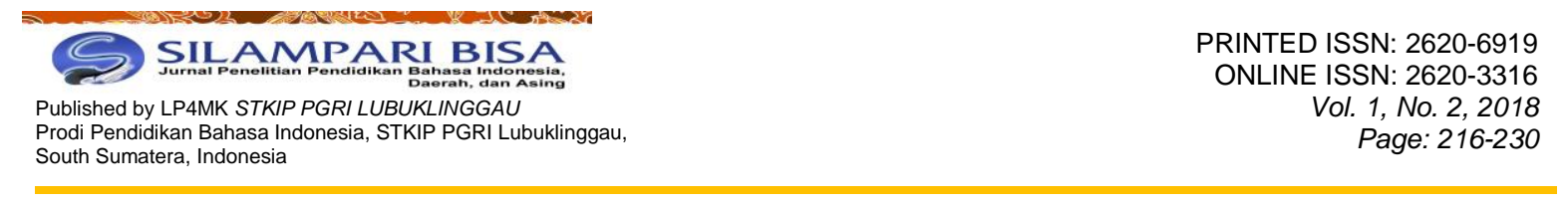

\title{
NILAI SOSIAL DAN MORALITAS DALAM NASKAH DRAMA JANJI SENJA KARYA TAOFAN NALISAPUTRA
}

\author{
Agung Nugroho \\ Program Studi Pendidikan Bahasa Indonesia, STKIP PGRI Lubuklinggau \\ Jalan Mayor Toha, Kelurahan Air Kuti, Kota Lubuklinggau, Indonesia \\ Email: agung.nugroho12354@gmail.com
}

Submitted: 18-November-2018

Accepted : 31-December-2018
Published: 31-December-2018

DOI: $10.31540 /$ silamparibisa.v1i2.153

URL: https://doi.org/10.31540/silamparibisa.v1i2.153

\begin{abstract}
Abstrak
Tujuan penelitian ini untuk mendeskripsikan nilai sosial dan nilai moral naskah drama. Naskah drama yang digunakan berjudul Janji Senja Karya Taofan Nalisaputra. Penelitian ini menggunakan metode deskriptif kualitatif. Teknik pengumpulan data menggunakan teknik dokumentasi. Teknik analisis data dilakukan dengan cara membaca, pengkodingan, pendeskripsian, interprestasi, dan kesimpulan. Hasil penelitian ini merupakan deskripsi kajian nilai sosial dan nilai moral naskah drama Janji Senja karya Taofan Nalisaputra. Hasil dari kajian nilai sosial yang mendominasi naskah drama Janji Senja karya Taofan Nalisaputra yaitu nilai sosial diri dengan orang lain hal ini terlihat dari kutipan "Istri harus patuh pada suami, ujaran yang kasar berdampak menyakiti hati orang lain, kebencian yang memutuskan tali darah dalam tubuh, lebih mementingkan orang lain dari pada ibunya sendiri". Hal ini tampak jelas dituangkan oleh pengarang dalam naskahnya. Sedangkan nilai moral naskah drama Janji Senja karya Taofan Nalisaputra melingkupi beberapa aspek di antaranya, berbentuk tingkah laku yang sesuai dengan kesusilaan, budi pekerti, dan juga akhlak. Berdasarkan hasil tersebut terlihat jelas jika naskah drama Janji Senja karya Taofan Nalisaputra sangat kental akan nilai sosial dan moral hal ini karena naskah drama yang diangkat berkaitan langsung dengan kehidupan sehari-hari di masyarakat.
\end{abstract}

Kata kunci: nilai sosial dan moralitas, naskah drama

\section{SOCIAL VALUE AND IN MORALITY OF THE DRAMA SCRIPT JANJI SENJA BY TAOFAN NALISAPUTRA}

\begin{abstract}
The purpose of this study was to describe the social values and moral values of drama scripts. The drama manuscript used was titled Janji Senja by Taofan Nalisaputra. This study used descriptive qualitative method. The results of this study are a description of the study of social values and moral values of the drama drama Janji Senja by Taofan Nalisaputra. The results of the social value study that dominates the drama script Janji Senja by Taofan Nalisaputra namely the social value of self with others this is seen from the quote "The wife must obey the husband, rude speech affects other people's hearts, hatred that cuts the cord of blood in body, more concerned with others than his own mother ". This is clearly stated by the author in the manuscript. Whereas the moral values of the Janji Senja drama script by Taofan Nalisaputra cover several aspects including, in the form of behavior that is appropriate to decency, character, and morals. Based on these results, it is clear that the drama of the writing of Janji Senja by Taofan Nalisaputra is very strong in terms of social and moral values because the drama plays are directly related to daily life in the community.
\end{abstract}

Keywords: social values and morality, drama scripts 


\section{A. Pendahuluan}

Karya sastra merupakan salah satu jenis karya seni yang mengungkapkan pikiran, perasaan, daya khayal seorang pengarang. Menurut Luxemburg (dalam Dewi, 2008:2) "Sastra didefinisikan sebagai suatu ciptaan, suatu kreasi yang merupakan luapan emosi yang spontan dan sastra itu bersifat otonom, tidak mengacu pada sesuatu yang lain, dan mempunyai koherensi antara unsurunsurnya. Sastra merupakan hasil cipta yang mengungkapkan pribadi manusia berupa pengalaman, semangat, ide, prevasi, pemikiran, dan keyakinan dalam suatu gambaran konkret yang mampu membangkitkan gairah yang dapat tersalurkan dengan alat bahasa. Dengan melihat dan mendengarkan karya sastra yang indah, maka keindahan tersebut dapat menggetarkan sukma, dapat menimbulkan keharuan, kemesraan, kebencian, atau pandangan hati, dan dendam bagi penikmatnya.

Hasil dari karya sastra baik yang berupa puisi, prosa, maupun drama telah kita ketahui bersama bentuknya. Prosa maupun puisi memiliki karateristik yang berbeda-beda dan secara langsung akan berbeda pula dalam mengapresiasinya. Begitu pula dengan prosa yang beragam bentuknya, juga membutuhkan pemahaman tersendiri. Salah satu karya sastra prosa ialah drama.

Drama adalah salah satu genre sastra yang hidup dalam dunia, yaitu "Seni sastra dan seni pertunjukan atau teater. Orang yang menganggap drama sebagai seni pertunjukan akan membuang fokus itu sebab perhatiannya harus dibagi rata dengan unsur lainnya (Mulyana, 2006:144). Sastra, khususnya drama tentu memiliki tujuan yang hendak dicapai baik itu secara berkelompok maupun secara individu. Menurut Sadikin (2010:42) "Drama mengandung pandangan yang berhubungan dengan renungan atau kontemplasi batin. Kontemplasi batin merupakan berbagai macam problema yang berhubungan dengan kehidupan manusia seperti norma-norma, nilai agama, pendidikan dan kebudayaan. Kesemua problema ini di dalam drama dikemas ke dalam unsur-unsur yang membangunnya yaitu unsur intrinsik dan unsur ekstrinsik".

Drama dapat memberikan manfaat yang besar bagi pembacanya, jika pembaca benar-benar menghayati dan memahami pesan yang disampaikannya. 
Dengan memahami isi yang terkandung dalam suatu drama, pembaca akan memperoleh nilai-nilai kehidupan yang terkandung di dalamnya. Pemahaman terhadap isi dan makna yang terkandung dalam suatu drama tidak lepas dari pemahaman terhadap unsur- unsur yang terkandung dalam drama itu sendiri. Secara umum kompetensi dasar drama memiliki dua unsur, yaitu unsur intrinsik dan ekstrinsik.

Noermanzah (2017:28) menjelaskan bahwa karya sastra tercipta sebagai suatu kegiatan kreatif dan inovatif dalam betuk tulisan atau tercetak yang memiliki nilai keindahan dan tentunya tidak dapat dipisahkan dengan pengajaran bahasa oleh karena keduanya saling melengkapi, terutama sekali dalam pembelajaran bahasa yang selalu menggunakan karya sastra sebagai objek utamanya dalam menjelaskan dari ciri dan fungsi bahasa tersebut. Oleh karena itu, umumnya setiap karya sastra memiliki dua unsur yaitu unsur ektrinsik dan unsur intrinsik yang terbentuk dari bahasa yang indah. Unsur ektrinsik yaitu unsur luar yang mempengaruhi karya sastra itu, misalnya nilai moral, nilai agama, nilai sosial, dan nilai budaya. Sedangkan unsur intrinsik yaitu unsur yang berada dalam karya sastra itu sendiri, misalnya alur, penokohan, tema, latar, sudut pandang, gaya bahasa dan lain-lain".

Berdasarkan penjelasan di atas unsur ekstrinsik dan intrinsik memiliki peranan yang fital terhadap pemahaman sebuah karya sastra terutama karya sastra drama. Dengan dipahaminya unsur-unsur tersebut pembaca akan lebih mudah menyerap atau memahami setiap pesan atau tujuan yang ingin disampaikan oleh pengarang. Dalam pemahaman unsur ekstrinsik khususnya nilai sosial dan moral naskah drama, seorang pembaca harus memahami unsur intrinsik sebagai penunjang dalam memahami setiap unsur ekstrinsik.

Pemahaman unsur sosial pada naskah drama akan memberikan gambaran nilai-nilai sosial kemasyarakatan. Nilai sosial tersebut melingkupi hubungan pengarang dengan masyarakat dan hasil karya sastra dengan masyarakat. Nilai sosial akan memudahkan pembaca untuk memahami nilai sosial masyarakat drama, sehingga pemahaman terhadap isi drama dapat menyeluruh. Oleh sebab 
itu dalam mengkaji naskah drama tersebut harus tepat dalam penggunaan pendekatan, dalam hal ini pendekatan sosiologi.

Pendekatan sosiologi adalah pendekatan yang berhubungan dengan kehidupan di masyarakat, sejauh mana pengarang menghubungkan karyanya dengan kehidupan masyarakat sebenarnya. Jadi pendekatan sosiologi adalah pendekatan yang menitik beratkan pada hubungan kemasyarakatan, sehingga dalam menerapkanya memerlukan pemahaman kehidupan dari pengarangnya dan lingkungan masyarakatnya. Dengan pedekatan sosiologi nantinya naskah drama tidak hanya sebatas strukturnya saja akan tetapi nilai-nilai yang lain akan dipahami dengan baik. Selain nilai sosial naskah drama juga terdapat nilai moral yang turut berperan dalam pembentukan karya sastra tersebut.

Moral adalah sistem nilai tentang bagaimana kita harus hidup secara baik sebagai manusia (Burhanudin, 1997:3). Moral mengacu pada akhlak yang sesuai dengan peraturan sosial, atau menyangkut hukum atau adat kebiasaan yang mengatur tingkah laku (Chaplin. 2006:64). Berdasarkan penjelasan para ahli di atas, moral adalah Sistem nilai yang mengacu pada akhlak yang sesuai dengan peraturan yang ada. Baik hukum adat istiadat maupun yang mengatur tingkah laku dalam bermasyarakat. Kemudian, menurut Grinitha (2015:202) nilai moral dalam suatu cerita biasanya bertujuan sebagai saran yang berhubungan dengan ajaran moral tertentu yang bersifat praktis dan dapat diambil atau ditafsirkan melalui cerita yang berkaitan dengan masalah kehidupan, misalnya sikap, tingkah laku, dan sopan santun dalam pergaulan.

Naskah drama Janji Senja karya Taofan Nalisaputra adalah salah satu bentuk drama yang didalamnya banyak terkandung nilai-nilai sosial dan moral. Drama ini menceritakan realita kehidupan pada masa sekarang ini, dimana orang tua yang begitu sayang kepada anaknya. Dalam hal ini seorang ibu yang sayang kepada anak akan tetapi sang anak justru sebaliknya. Dalam drama Janji Senja karya Taofan Nalisaputra ini juga mengisahkan penantian seorang istri kepada suami yang sangat setia menunggu hingga akhir hidupnya. Hal ini yang membuat isi dalam drama ini sangat kental dengan nilai sosial dan moral sehingga patut untuk dipahami oleh setiap pembaca. Berdasarkan penjelasan di atas, penulis mengkaji naskah drama Janji Senja Karya Taofan Nalisaputra guna menemukan 
nilai sosial dan moral, sehingga nantinya naskah drama ini dapat terpahami tidak hanya dari strukturnya akan tetapi juga unsur ekstrinsiknya.

Hasil penelitian relevan terkait nilai sosial dan moral terhadap naskah drama yaitu penelitian yang dilakukan oleh Eryanti dkk. (2015:1) tentang nilai moral yang terkandung dalam kumpulan naskah drama Kalangkang Urang karya Arthur S. Nalan. Hasil penelitian ini yaitu pertama struktur cerita; tema yang terkandung di setiap naskah drama diantaranya tema keagamaan, cinta, politik, moral, dan sosial; alur yang digunakan yaitu alur maju dan maju mundur; tokoh yang dianalisis yaitu tokoh utama dan tokoh tambahan; watak tokoh didapat dengan cara mengamati sikapnya, omongannya, pikirannya, keaadaan fisiknya, dan apa yang diungkapkan serta dipikirkan oleh tokoh mengenai dirinya sendiri; latar yang terdapat dalam kumpulan naskah drama Kalangkang Urang yaitu latar tempat, latar waktu dan latar keadaan; di setiap drama-dramanya mempunya amanat yang positif yang bisa diterapkan dalam kehidupan sehari-hari. Kedua nilai moral, dalam kumpulan naskah drama Kalangkang Urang terdapat 31 nilai moral diantarnya 6 nilai moral manusia terhadap Tuhan, 7 nilai moral manusia terhadap pribadi, 14 nilai moral manusia terhadap manusia lainnya, 2 nilai moral manusia terhadap alam, dan 2 nilai moral manusia dalam mengejar kepuasan lahiriah dan batiniah.

Penelitian relevan berikutnya pernah dilakukan oleh Muhtadin \& Murniasih, (2018:154) tentang nilai moralitas dalam Novel Negeri di Ujung Tanduk Karya Tere Liye. Hasil penelitian ini menunjukkan bahwa nilai moral terbagi ke dalam nilai hubungan manusia dengan manusia; nilai hubungan manusia dengan manusia lain atau sosial dan alam; dan hubungan manusia dengan Tuhan. Nilai moralitas dalam novel Negeri di Ujung Tanduk karya Tere Liye, antara lain: 1) hubungan manusia dengan manusia lain berupa harga diri, eksistensi diri, rasa percaya diri, maut, takut, dendam, rindu, kesepian, dan keterombang-ambingan, kejujuran, menjaga kesucian diri dari sikap rakus, mengembangkan keberanian, kerja keras, ceria, sabar, ulet, teguh, visioner,terbuka, mandiri, pemberani,tegar, optimis, dengki, munafik, tanggung jawab, reflektif, prinsip, disiplin, percaya diri, dan rakus; 2) hubungan manusia dengan manusia lain atau sosial dan alam 
berupa saling mengenal, kerja sama, kepedulian, kemunafikan, rasa peduli, persahabatan, saling membantu, senyuman, dan pengkhianatan; serta 3) hubungan manusia dengan Tuhan berupa mentauhidkan Tuhan dan menghindari syirik, , salat yang dilakukan oleh manusia,bertaqwa dan memohon pertolongan dengan doa-doa sebagai suatu kesadaran bahwa semua yang ada di alam semesta ini milik Tuhan YME.

Dari beberapa hasil penelitian relevan tersebut, menunjukkan bahwa penelitian tentang nilai sosial dan nilai moral dalam naskah drama Janji Senja karya Taofan Nalisaputra, belum ada yang mengkaji. Untuk itu pentinya dilakukan penelitian khusus sehingga mampu memberikan manfaat sebagai salah satu model bahan ajar naskah drama di sekolah apabila mengandung nilai sosial dan nilai moral yang baik dan mengandung nilai pendidikan karakter.

\section{B. Metode Penelitian}

Pendekatan yang digunakan dalam penelitian ini adalah pendekatan deskriptif kualitatif dalam sudut pandang penelitian kepustakaan. Dikatakan deskriptif kualitatif karena penelitian ini, penulis mendeskripsikan data yang dikaji berupa nilai Sosial dan Moral naskah drama Janji Senja karya Taofan Nalisaputra. Dikatakan deskriptif kualitatif karena dalam menjelaskan konsep-konsep yang berkaitan antara yang satu dengan yang lain, penulis menggunakan kata-kata atau kalimat bukan angka-angka statistik dengan mengacu pada struktur yang benar serta menggunakan pemahaman yang mendalam. Jenis penelitian kepustakaan ini dilakukan dengan menganalisis naskah drama Janji Senja karya Taofan Nalisaputra.

Data dalam penelitian ini adalah kutipan-kutipan cerita yang mencerminkan nilai-nilai sosial dan moral naskah drama Janji Senja karya Taofan Nalisaputra. Sumber data dalam penelitian ini adalah naskah drama Janji Senja Karya Taofan Nalisaputra. Kegiatan penelitian ini, penulis bertindak sebagai instrument utama atau insrumen kunci dalam pengumpulan data. Dikatakan demikian karena dalam proses penelitian, penulis sendiri yang melakukan penelahaan terhadap cerita yang diteliti. Hal ini sejalan dengan pendapat yang mengatakan bahwa dalam "Penelitian kualitatif keberhasilannya bergantung pada kemampuan kemampuan 
orang menggunakan alat tersebut". Dengan kata lain, penulis yang paling menentukan keberhasialan penelitian (Ratna, 2007:363).

Pengumpulan data dalam penelitian ini di lakukan dengan tiga teknik yaitu: 1) teknik baca, dengan cara Membaca dengan seksama dengan berulang-ulang. Kegiatan membaca dalam hal ini, penulis membaca secara seksama naskah drama Janji Senja karya Taofan Nalisaputra. 2) Teknik infentarisasi, dengan cara mencari dan mengumpulkan sejumlah data dari naskah drama Janji Senja karya Taofan Nalisaputra. Data yang dicari adalah nilai-nilai Sosial dan Moral naskah drama Janji Senja karya Taofan Nalisaputra. 3) Teknik pencatatan, setelah baca simak, inventarisasi, hasil yang diperoleh dicatat dan dipilah-pilah satu persatu, sesuai dengan unsur-unsur yang dicari. Disusun secara sitematis oleh penulis agar mudah untuk dipahami dan diolah.

Kemudian, langkah-langkah yang ditempuh dalam menganalisis data adalah melakukan pembacaan secara berulang-ulang terhadap naskah drama Janji Senja karya Taofan Nalisaputra, menandai setiap data yang mengandung nilai-nilai sosial dan moral (pemodean data), seluruh data yang diperoleh dari hasil pembacaan dan pengodean dipilah berdasarkan objek penelitian, dan data yang telah dipilah-pilah dideskripsikan sebagai mana adanya dan disusun dalam bentuk laporan. Analisis menurut Sangidu (2005:73) bertujuan menyederhanakan dalam bentuk yang lebih mudah dibaca diinterprestasikan.

\section{Hasil Penelitian dan Pembahasan}

\section{Hasil Penelitian}

a. Sosiolitas Naskah drama "Janji Senja” Karya Taofan Nalisaputra

Di dalam teks drama Janji Senja karya Taofan Nalisaputra terkandung beberapa konteks sosial yang terjadi di dalam masyarakat, realita itu antara lain:

1) Istri Harus Patuh dan Berbakti Kepada Suami

Realita sosial bahwa istri harus tunduk dan patuh terhadap suami ini ditunjukan kesetiaan sang ibu yang menunggu suaminya akan pulang kala senja sampai akhir hayatnya walaupun suaminya tak kunjung datang jua. Seperti tampak pada kutipan berikut: 
Ibu : (Berbicara pada senja) "Kau berjanji akan datang saat senja. Dan aku yakin kau akan datang. Aku yakin kau tak akan melupakan cinta kita, melupakanku dan buah hati kita. Aku akan tetap menunggumu, sampai senja terakhir hidupku."

Kutipan tersebut sebagai bukti nyata sekaligus menunjukan realita sosial yang ada di dalam masyarakat. Istri setelah menikah harulah tunduk dan patuh pada suaminya. Walaupun suami tak kunjung datang jua, namun sang istri harus tetap menunggu. Karena surganya istri ada di suami, namun ini juga menjadi resiko bagi sebuh pernikahan.

2) Ujaran yang Kasar Berdampak Menyakiti Hati Orang Lain

Realitas sosial, saat berbicara seorang anak harusnya berfikir terlebih dahulu. Agar ujaran yang disampaikan tidak menyakiti hati orang lain. seperti tampak pada kutipan berikut:

Anak : "Mengapa Ibu harus menunggunya seperti ini? Menunggu seseorang yang tak jelas dan tak pasti kapan ia kan kembali. Dia sudah lupa dengan kita, dan ku pikir ia memang sudah lupa dengan kita. Coba ibu pikirkan, sedari dulu waktu aku masih dalam kandungan hingga kini aku dewasa, sudah bertahun-tahun lamanya ia tak pernah kembali ke rumah ini. Bahkan aku sendiri tak pernah tau wajahnya (Diam sejenak). Ku pikir sebaiknya lbu menikah lagi dan melupakan lelaki tidak bertanggung jawab itu".

Ibu : "Pakai otakmu...!!!!".

Berdasarkan kutipan tersebut tampak bahwa ibu tidak nyaman atas ujaran yang dilontarkan anaknya. Yang mana membuat hati ibu sakit. Di realita sosial yang terjadi di dalam masyarakat, banyak sekali anak-anak yang sering melontarkan ujaran yang kasar, tampak memikirkan hati seorang ibu. Mereka tak sadar bahwa yang mereka ujarkan itu, tak khala dapat memencing keributan yang besar.

3) Kebencian yang Memutusakan Tali Darah yang Mengalir dalam Tubuh

Realitas sosial seharusnya sang anak bisa sabar dalam menunggu akan kehadiran sang ayah, bukan hanya memutusakan suatu keputusan dari satu pihak saja. Seperti tampak pada kutipan berikut:

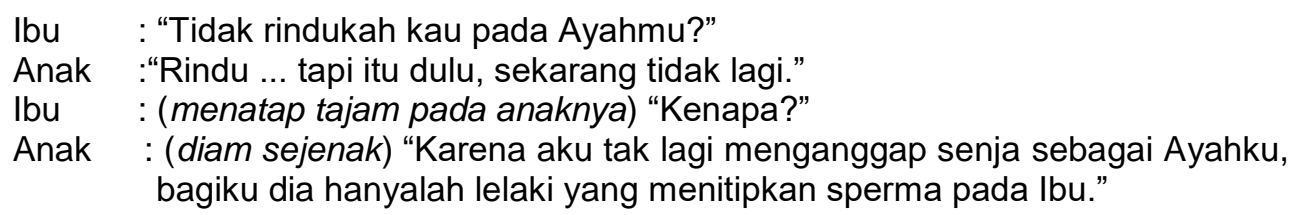
bagiku dia hanyalah lelaki yang menitipkan sperma pada Ibu."

Kutipan tersebut sebagai bukti nyata sekaligus menunjukan realita sosial yang ada di dalam masyarakat. Bahwasanya seorang anak tidak boleh 
memutuskan tali darah terhadap seorang ayah, karena bagaimana pun juga seorang ayah tetaplah sebagai ayah tidak bisa menjadi bekas. Seorang anak dalam menaggapi masalah yang seperti ini harusnya tidak hanya dari satu pihak.

4) Lebih Mementingkan Orang Lain dari pada Ibunya Sendiri

Realitas sosial bahwa anak seharusnya tunduk dan mentaati ujaran apapun yang ibu sampaikan. Namun hal ini tidak tercermin pada sosok sang anak yang lebih memilih calon suaminya ketimbang bertahan dengan ibunya. Seperti tamapak pada kutipan berikut:

\footnotetext{
Ibu : "Kau mau kemana?"

Anak : "Aku mau pergi... Dia sudah menungguku!!"

Ibu : "Kau tak mau menunggu ayahmu?"

Anak : "Ayah mana yang harus kutunggu? Sudah berhari-hari aku disini, tapi ia tak jua datang. Sudahlah Bu, jika ia memang datang aku tak mau mengenalinya sebagai ayahku."

Ibu : "Jaga ucapanmu! Maksudmu apa mengatakan hal demikian?"

Anak : "Sudah sepantasnya kan, Ayah macam apa namanya yang tega meninggalkan anak dan istrinya begitu lama. Hingga anaknya akan dipersunting orang pun ia tak ada."

Ibu : "Ayahmu tak seperti itu. Dia laki-laki yang bertanggung-jawab."

Anak : "Ibu sudah mengatakan itu berulang kali... Sejak dulu aku masih kecil. Tapi apa? Mana buktinya? Omong kosong."

Ibu : "Kau anak durhaka!"

Anak : "Biarlah, tak apa aku durhaka pada orang yang telah durhaka pada keluarganya."

(Ibu kemudian terdiam. Matanya berkaca-kaca, air matanya nampak akan jatuh. Sang anak berlalu meninggalkan ibunya. Ibu masih diam menatap senja dengan linangan air mata).
}

Kutipan tersebut sebagai bukti nyata sekaligus menunjukan realita sosial yang sering terjadi di dalam masyarakat. Menuruti perintah sang ibu, itu adalah hak mutlak yang wajib diikuti oleh sang anak. Karena ibu adalah sosok yang sangat di hormati, dicintai dan di lindungi. Namun dewasa ini sering kali terjadi hal yang seperti ini, sangat di sayangkan sekali. Lebih mementingkan laki-laki, dari pada ibunya sendiri. Harusnya hal ini tidak boleh terjadi.

b. Moralitas Naskah drama Janji Senja Karya Taofan Nalisaputra

\section{Moral Deskriptif}

Moral deskriptif yaitu moral atau etika yang berusaha meneropong secara kritis dan rasional sikap dan perilaku manusia dan apa yang dikejar oleh manusia dalam hidup ini sebagai sesuatu yang bernilai. Moral deskriptif 
memberikan fakta sebagai dasar untuk mengambil keputusan tentang perilaku atau sikap yang mau diambil.

Nilai moral deskriptif tampak pada kutipan berikut:

lbu : :Ayahmu tak seperti itu. Dia laki-laki yang bertanggungjawab."

Anak : "lbu sudah mengatakan itu berulang kali... Sejak dulu aku masih kecil. Tapi apa? Mana buktinya? Omong kosong."

Ibu : :Kau anak durhaka!"

Anak : :Biarlah, tak apa aku durhaka pada orang yang telah durhaka pada keluarganya."

Ibu kemudian terdiam. Matanya berkaca-kaca, air matanya nampak akan jatuh. Sang anak berlalu meninggalkan ibunya. Ibu masih diam menatap senja dengan linangan air mata.

Ibu : (Berbicara Pada Senja)

"Kau berjanji akan datang saat senja. Dan aku yakin kau akan datang. Aku yakin kau tak akan melupakan cinta kita, melupakanku dan buah hati kita." Aku akan tetap menunggumu, sampai senja terakhir hidupku.

Berdasarkan kutipan di atas nampak sekali tokoh ibu mempertahan sesuatu yang bernilai yaitu suaminya. Yang mana walau ibu ditinggalkan oleh anaknya dia tetap menunggu suaminya pulang. Dilihat dari gambaran di atas tampak terlihat nilai yang diperthankan oleh tokoh ibu adalah kesetiaan.

\section{Moral Normatif}

Moral normatif yaitu moral atau etika yang berusaha menetapkan berbagai sikap dan pola ideal yang seharusnya dimiliki oleh manusia dalam hidup ini sebagai sesuatu yang bernilai.

Anak : : (Berlari mendekati ibunya lalu memeluknya) "Ibu maafkan aku...!!! " (Sambil mengis dalam pelukan ibu)

Ibu : (Melepas pelukannya dan dengan tangannya memegang dagu mengangkat wajah anaknya) "Ayahmu terlalu bersih. Ibu tidak mungkin bisa menggantikannya dengan orang lain."

(Diam sejenak aling berpandangan)

"Jangan lagi berpikir untuk mencari orang lain sebagai pengganti Ayahmu. Karena Ibu yakin Ayahmu akan datang pada suatu senja."

Dari kutipan di atas dapat terlihat bahwa sikap tokoh anak memiliki moral sikap baik yang mana ia mau meminta maaf kepada ibunya karena ia sadar bahwa apa yang dikatakannya salah.

\section{Moral Pribadi}

Menyangkut kewajiban dan perilaku manusia terhadap diri sendiri untuk mencapai kesucian kehidupan pribadi, kebersihan hati nurani dan yang berakhlak luhur.

Anak : :Ya Tuhan... Apa yang barusan aku katakan. Aku tak seharusnya berkata itu pada ibu." "Ibu maafkan aku. " (Sedikit menangis) 
Berdasarkan kutipan di atas jelas bahwa nilai religius tokoh anak masih tertanam di dalam dirinya, karena tokoh anak menyadari bahwa apa yang dikatakannya salah. Spontanitas ia menyebut nama Tuhan dan meminta maaf kepada ibunya.

4. Moral Sosial

Mengenai kewajiban, sikap dan perilaku sebagai anggota masyarakat yang berkaitan dengan nilai sopan santun, tata krama dan saling menghormati. Moral sosial menyangkut hubungan manusia dengan manusia baik secara langsung maupun secara kelembagaan (keluarga, masyarakat, negara), sikap kritis terhadap pandangan-pandangan dunia danidiologi-idiologi maupun tanggung jawab umat manusia terhadap lingkungan hidup.

\footnotetext{
Anak : "Aku diterima bekerja di sebuah perusahaan di kota. Aku berencana akan tinggal disana, dan ku harap lbu mau ikut bersamaku tinggal di kota."

Ibu : : "Ibu masih ingin menunggu Ayahmu di sini, di rumah ini setiap senja."
}

Dari kutipan di atas, nilai moral sosial terlihat jelas adanya interaksi antara ibu dan anak. Yang mana tokoh anak mengajak ibunya untuk tinggal bersamanya di kota.

\section{Pembahasan}

a. Nilai Sosial

Di dalam teks drama Janji Senja karya Taofan Nalisaputra terkandung beberapa konteks sosial yang terjadi di dalam masyarakat, realita itu antara lain: berupa istri harus patuh dan berbakti kepada suami. Realita sosial bahwa istri harus tunduk dan patuh terhadap suami ini ditunjukan kesetiaan sang ibu yang menunggu suaminya akan pulang kala senja sampai akhir hayatnya walaupun suaminya tak kunjung datang jua. Realita sosial yang ada di dalam masyarakat. Istri setelah menikah harulah tunduk dan patuh pada suaminya. Walaupun suami tak kunjung datang jua, namun sang istri harus tetap menunggu. Karena surganya istri ada di suami, namun ini juga menjadi resiko bagi sebuah pernikahan.

Kemudian, nilai sosial berupa ujaran yang kasar berdampak menyakiti hati orang lain. Realitas sosial, saat berbicara seorang anak harusnya berfikir terlebih dahulu. Agar ujaran yang disampaikan tidak menyakiti hati orang lain. Banyak 
sekali anak-anak yang sering melontarkan ujaran yang kasar, tampak memikirkan hati orang tua. mereka tak sadar bahwa yang mereka ujarkan itu, tak khala dapat memancing keributan yang besar.

Kebencian yang memutusakan tali darah yang mengalir dalam tubuh. Realitas sosial seharusnya sang anak bisa sabar dalam menunggu akan kehadiran sang ayah, bukan hanya memutusakan suatu keputusan dari satu pihak saja. Bahwasanya seorang anak tidak boleh memutuskan tali darah terhadap seorang ayah, karena bagaimana pun juga seorang ayah tetaplah sebagai ayah tidak bisa menjadi bekas. Seorang anak dalam menaggapi masalah yang seperti ini harusnya tidak hanya dari satu pihak.

Lebih mementingkan orang lain dari pada ibunya sendiri. Realitas sosial bahwa anak seharusnya tunduk dan mentaati ujaran apapun yang ibu sampaikan. Namun hal ini tidak tercermin pada sosok sang anak yang lebih memilih calon suaminya ketimbang bertahan dengan ibunya. Menuruti perintah sang ibu, itu adalah hak mutlak yang wajib diikuti oleh sang anak. Karena ibu adalah sosok yang sangat di hormati, dicintai dan di lindungi. Namun dewasa ini sering kali terjadi hal yang seperti ini, sangat di sayangkan sekali. Lebih mementingkan lakilaki, dari pada ibunya sendiri. Harusnya hal ini tidak boleh terjadi.

Di dalam teks drama Janji Senja karya Taofan Nalisaputra terkandung beberapa nilai yang ada di masyarakat. Nilai-nilai itu antara lain:

Nilai moral. Dalam teks drama Janji Senja karya Taofan Nalisaputa menunjukan adanya pertengkaran antara ibu dan anak, yang mana seorang anak ingin memutuskan tali kekeluargaan terhadap sang ayah. Pertengkaran ini seharusnya tidak terjadi, ujaran yang disampaikan sang anak seharusnya tidak perlu dilontarkan. Karena ini bisa menyakiti hati sang ibu. memutusakan tali kekeluargaan atau hubungan darah terhadap keluarga seharusnya tidak boleh dilakukan. Disini ada niali moral yang bisa kita petik yaitu sekesal apapun kita terhadap seorang ayah jangan sampai memutuskan tali darah yang melekat pada tubuh. Seharusnya permasalahan seperti ini harus ditanggapi dengan kepala dingin dan bijak.

Nilai Religi. Dalam teks drama ini muncul nilai religi yang mana sang anak meminta restu untuk menikah terhadap ibunya, namun ibu menyuruh sang anak 
juga meminta restu terhadap ayahnya. Di dalam islam sendiri, ketika seorang anak gadis akan menikah, pernikahannya itu haruslah dinikahi oleh ayahnya sendiri, jika ayahnya masih hidup. Tapi jika ayahnya sudah meninggal boleh untuk diwakilkan wali.

Nilai Sosial. Dalam drama diceritakan anak yang lebih memilih pergi demi menikah dengan calon suaminya dan meninggalkan ibu sendirian di desa. Disini harusnya mucul suatu kesadaran oleh sang anak, bahwa tindakan yang ia lakukan dapat menyakiti hati sang ibu. tak jarang keadaan ini sering kali memencing keributan. Harusnya sang anak, harus bisa berfikir dan memutuskan sesuatu secara bijak, jangan hanya memutuskan dengan emosi belaka. Seharusnya ia harus berpikir secara logis, bahawa ibu adalah adalah prioritas utama dari pada orang lain.

\section{b. Nilai Moral}

Nlai moral dalam teks drama Janji Senja karya Taofan Nalisaputra terdiri atas nilai moral deskriptif, nilai moral normatif, nilai moral pribadi, dan nilai moral sosial. Hal ini berbeda dengan hasil penelitian Penelitian relevan berikutnya pernah dilakukan oleh Muhtadin \& Murniasih (2018:154) tentang nilai moralitas dalam Novel Negeri di Ujung Tanduk Karya Tere Liye. Hasil penelitian ini menunjukkan bahwa nilai moral terbagi ke dalam nilai hubungan manusia dengan manusia; nilai hubungan manusia dengan manusia lain atau sosial dan alam; dan hubungan manusia dengan Tuhan.

Nilai moral deskriptif dalam dalam teks drama Janji Senja karya Taofan Nalisaputra berupa nilai moral atau etika yang berusaha meneropong secara kritis dan rasional sikap dan perilaku manusia dan apa yang dikejar oleh manusia dalam hidup ini sebagai sesuatu yang bernilai. Moral deskriptif memberikan fakta sebagai dasar untuk mengambil keputusan tentang perilaku atau sikap yang mau diambil.

Kemudian, nilai moral normatif yang ditemukan berupa moral normatif berupa moral atau etika yang berusaha menetapkan berbagai sikap dan pola ideal yang seharusnya dimiliki oleh manusia dalam hidup ini sebagai sesuatu yang 
bernilai. Terdapat juga nilai moral pribadi yang menyangkut kewajiban dan perilaku manusia terhadap diri sendiri untuk mencapai kesucian kehidupan pribadi, kebersihan hati nurani dan yang berakhlak luhur. Jelas bahwa nilai religius tokoh anak masih tertanam di dalam dirinya, karena tokoh anak menyadari bahwa apa yang dikatakannya salah. Spontanitas ia menyebut nama Tuhan dan meminta maaf kepada ibunya.

Terdapat juga nilai moral sosial teks drama Janji Senja karya Taofan Nalisaputra mengenai kewajiban, sikap dan perilaku sebagai anggota masyarakat yang berkaitandengan nilai sopan santun, tata krama dan saling menghormati. Moral sosial menyangkut hubungan manusia dengan manusia baik secara langsung maupun secara kelembagaan (keluarga, masyarakat, negara), sikap kritis terhadap pandangan-pandangan dunia dan idiologi-idiologi maupun tanggung jawab umat manusia terhadap lingkungan hidup.

\section{Simpulan}

Dari hasil penelitian ini dapat disimpulkan bahwa nilai sosial yang mendominasi naskah drama Janji Senja karya Taofan Nalisaputra yaitu nilai sosial diri dengan orang lain hal ini terlihat dari kutipan "Istri harus patuh pada suami, ujaran yang kasar berdampak menyakiti hati orang lain, kebencian yang memutuskan tali darah dalam tubuh, lebih mementingkan orang lain dari pada ibunya sendiri". Hal ini tampak jelas dituangkan oleh pengarang dalam naskahnya. Sedangkan nilai moral naskah drama Janji Senja karya Taofan Nalisaputra melingkupi beberapa aspek di antaranya, berbentuk tingkah laku yang sesuai dengan kesusilaan, budi pekerti, dan juga akhlak. Berdasarkan hasil tersebut terlihat jelas jika naskah drama Janji Senja karya Taofan Nalisaputra sangat kental akan nilai sosial dan moral hal ini karena naskah drama yang diangkat berkaitan langsung dengan kehidupan sehari-hari di masyarakat. 


\section{Daftar Pustaka}

Burhanuddin, Salam. (1997). Etika Sosial. Jakarta: PT Rineka Cipta.

Capplin, Hanna. (2006). Psikologi Umum. Jakarta: Kencana.

Dewi, Rusmana. (2008). Diktat Sejarah Sastra. Lubuklinggau: STKIP-PGRI Lubuklinggau (tidak dipublikasikan).

Eryanti, Wulan Nur, dkk. (2015). Analisis Struktur dan Nilai Moral dalam Kumpulan Naskah Drama "Kalangkang Urang" Karya Arthur S. Nalan. Dangiang Sunda, 3 (2), http://antologi.upi.edu/file/jurnal_indonesia_uul.pdf

Grinitha, V. (2015). Nilai-Nilai Moral dalam Novel Habiburrahman El Shirazy (Tinjauan Struktural Genetik). BAHTERA : Jurnal Pendidikan Bahasa Dan Sastra, 14(2), 202. doi:10.21009/bahtera.142.08

Muhtadin, M., \& Murniasih, S. (2018). Moralitas dalam Novel Negeri di Ujung Tanduk Karya Tere Liye. Silampari Bisa: Jurnal Penelitian Pendidikan Bahasa Indonesia, Daerah, dan Asing, 1(1), 154-173. doi:10.31540/silamparibisa.v1i1.19

Mulyana. (2006). Drama. Bandung: Tarsito.

Noermanzah, N. N. (2017). Plot in a Collection of Short Stories "Sakinah Bersamamu" Works of Asma Nadia with Feminimism Analysis. Humanus, 16(1), 27. doi:10.24036/jh.v16i1.7015

Ratna. (2007). Model-Model Pembelajaran Mengembangkan Profesional. Jakarta: Rajawali Pers.

Sadikin, Mustofa. (2010). Kumpulan Sastra Indonesia. Jakarta: PT. Buku Kita.

Sangidu. (2005). Sosiologi Suatu Pengantar. Jakarta: Raja Grafindo Persada. 